\title{
Plant dieback under exceptional drought driven by elevation, not by plant traits, in Big Bend National Park, Texas USA
}

In 2011, Big Bend National Park, Texas, USA, experienced the most severe single year drought in its recorded history, resulting in significant plant mortality. We used this event to test how perennial plant response to drought varied across elevation, plant growth form and leaf traits. In October 2010 and October 2011, we measured plant cover by species at six evenly-spaced elevations ranging from Chihuahuan desert $(666 \mathrm{~m})$ to oak forest in the Chisos mountains (1920 m). We asked the following questions: what was the relationship between elevation and stem dieback and did susceptibility to drought differ among functional groups or by leaf traits? In 2010, pre-drought, we measured leaf mass per area (LMA) on each species. In 2011, the percent of canopy dieback for each individual was visually estimated. Living canopy cover decreased significantly after the drought of 2011 and dieback decreased with elevation. There was no relationship between LMA and dieback within elevations. The negative relationship between proportional dieback and elevation was consistent in shrub and succulent species, which were the most common growth forms across elevations, indicating that dieback was largely driven by elevation and not by species traits. Growth form turnover did not influence canopy dieback; differences in canopy cover and proportional dieback among elevations were driven primarily by differences in drought severity. These results indicate that the 2011 drought in Big Bend National Park had a large effect on communities at all elevations with average dieback for all woody plants ranging from $8 \%$ dieback at the highest elevation to $83 \%$ dieback at lowest elevations. 
1 Elizabeth F. Waring Texas Tech University, Department of Biological Sciences, Lubbock, TX

2 USA

3 Dylan W. Schwilk Texas Tech University, Department of Biological Sciences, Lubbock, TX USA

4 Corresponding Author: Dylan W. Schwilk, Texas Tech University, Department of Biological

$5 \quad$ Sciences, Lubbock TX USA. Email: dylan.schwilk@ttu.edu 


\section{INTRODUCTION}

The study of plant community structure over elevational gradients has played an important role in plant ecology (Merriam 1890, Whittaker 1965, Whittaker \& Neiring 1964, 1968). In arid environments, water availability can increase dramatically with elevation and can drive turnover in plant species over short geographical distances (Whittaker \& Neiring 1968, Allen, Peet, \& Baker 1991). Drought can result in plant mortality or in stem death and partial dieback (Sperry \& Ikeda 1997, Jacobson et al. 2008) and can lead to changes in the plant community structure (Lloret, Siscart, \& Dalmases 2004). Although precipitation in arid and semiarid ecosystems is highly variable from year to year (Noy-Meir 1973, Schwinning \& Sala 2004), a major decrease in annual precipitation could cause dramatic mortality or dieback for species near the limit of their ecological tolerance (Pockman \& Sperry 2000).

The Chisos Mountains of Big Bend National Park in southwest Texas have dense oakjuniper forest communities in the higher elevations while the lower elevation Chihuahuan desert communities are dominated by grasses, succulents, and drought-tolerant deciduous shrubs. The various plant communities in Big Bend National Park would be expected to respond to environmental stress differently due to different species morphology and physiology. Leaf traits can vary greatly among species and across plant communities. A leaf trait commonly used to measure energy invested per photosynthetic return is leaf mass per area $\left(\mathrm{LMA}, \mathrm{g} / \mathrm{cm}^{2}\right)$. Adaptations to prevent water loss, such as fibrous content and pubescence, will cause a thickening of the leaf, increasing its LMA (Monneveux \& Belhassen 1996) and there is usually a positive correlation between leaves with a high LMA and drought tolerance (Wright, Reich, \& Westoby 2001). However, if a severe drought does cause dieback in plants with high LMA, the greater carbon investment per leaf may require longer post-drought recovery times for 
construction of new leaves for those species than for species with low LMA (Witkowski \& Lamont 1991, Wright et al. 2004).

In 2011, Texas experienced the most severe drought in its recorded history (NeilsenGammon 2011, Combs 2011), which led to dramatic plant mortality in Big Bend National Park (Poulos 2014, Waring \& Schwilk personal observation). This drought was coupled with an unusual multi-day, severe freeze in February 2011, which likely exacerbated the effects of drought in addition to directly causing freezing damage (Poulos 2014). We used this event to test how perennial plant response to extreme drought varied across elevations, plant growth forms and leaf traits. We asked the following questions: What was the relationship between elevation and stem dieback; and were any elevational patterns driven by turnover in functional groups or in leaf trait changes? To answer the second question, we investigated if susceptibility to drought differed among functional groups or by species leaf traits. These questions lead to two competing hypotheses regarding the interaction of drought and elevation. First, we would expect there to be higher proportional dieback at the lower elevational sites due to absolutely lower precipitation during the drought. However, the plants at the lower elevations may have greater physiological tolerances to drought conditions, so a second hypothesis is that we could see less proportional dieback at lower elevations, especially as the 2011 departure from average conditions was greater at higher, rather than lower, elevations.

\section{METHODS}

\subsection{Site description}

Plant communities at Big Bend National Park range from succulent and deciduous shrub dominated lowlands, to desert grasslands at mid elevations, to juniper, oak, and pine forest at 
higher elevations. Precipitation in Big Bend National Park is seasonally uneven (NOAA 2013).

52 There is higher precipitation in the summer and fall months with very little precipitation in the winter and spring (Robertson et al. 2010). After years of wetter than normal conditions, 2011 was an extraordinarily dry year for Big Bend National Park (Neilson-Gammon 2011). The average annual precipitation increases with elevation: at the Chisos Basin meteorological station (1617 m above sea level) annual precipitation averaged $441.7 \mathrm{~mm}$ between 1947 and 2012, Panther Junction (1143 m) averaged $333.04 \mathrm{~mm}$ between 1955 and 2012, and Rio Grande Village (566 $\mathrm{m}$ ) averaged $167 \mathrm{~mm}$ annually in 2006 through 2012 (NOAA 2013). In 2011, however, the Chisos Basin received only $109 \mathrm{~mm}$ of precipitation, the Panther Junction Station received 64 $\mathrm{mm}$ precipitation and Rio Grande Village received $59 \mathrm{~mm}$ (NOAA 2013). This drought was coupled with extremely high temperatures in 2011 in Big Bend National Park. Prior to 2011, the Chisos Basin averaged 22 days with temperatures above $32^{\circ} \mathrm{C}$, while Panther Junction averaged 106 days, and Rio Grande Village averaged 154 days (NOAA 2013). However in 2011, the Chisos Basin experienced 63 days, Panther Junction had 151 days, and the Rio Grande Village had 234 days above $32^{\circ} \mathrm{C}$ (NOAA 2013). In addition to the severe drought, there was a multi-day freeze event in February of 2011 that probably contributed to plant dieback (NOAA 2013, Poulos 2014 for the Chisos Basin freeze).

We collected data at six elevations within the park ( $\sim 250 \mathrm{~m}$ apart vertically) in autumn of 2010 and 2011 (Table 1, conducted under permit BIBE-2010-SCI-0019 to DWS). The lower elevation sites were located along the Ross Maxwell Scenic Drive while the high elevation sites were along the Pinnacles Trail. Sites were selected to be near hiking trails and roads in 2010 . Sites were chosen with a north to northwest aspect with the exception of the lowest elevation site which was nearly level. In each of the two sampling years, fifty-meter-long transects were placed 
randomly within a $500 \mathrm{~m}$ radius of the GPS location for each site. The six sites are described in Table 1. Species were identified using Powell (1997) and Mueller (1940).

\subsection{Canopy cover measurements}

In 2010 and 2011, 4 to 12 fifty-meter-long line-intercept transects were run perpendicular to the slope at each site. The number of transects was dependent on the density of the cover at each site: sites with higher cover had fewer transects because we aimed for relatively even sampling effort at each site (number of transects per site in Table 1). Transect starting points were selected randomly each year. The intercepted distance of canopy cover was recorded for each individual woody plant. Overlapping canopies were measured individually leading to the possibility of having canopy cover $>1$. Herbaceous species were not identified to species but were grouped together and bare ground was recorded. In 2011, for each individual woody plant or succulent, the proportion of the total canopy that was dead was visually estimated and recorded as "dieback proportion" for each individual plant (tested by bending small twigs in the case that leaves were missing). Dieback data were not estimated in 2010 after preliminary observations indicated very little dieback ( $<2 \%$ of cover). We classified species according to growth form: tree, shrub, subshrub, or succulent. We defined trees as species that regularly grew as single stemmed individuals $>2 \mathrm{~m}$ tall; shrubs as species with mostly multi-stemmed individuals $<2 \mathrm{~m}$; subshrubs as individuals with some above ground woody stem and herbaceous growth above the base that would die back annually (e.g. equivalent to "chamaephyte" in Raunkiær classification, du Rietz 1931), and succulents included individuals of the families Agavaceae, Cactaceae, and Nolinaceae. Transects were treated as replicates nested within a site. All measurements were expressed on a per transect basis for analysis.

Total canopy cover for each individual was determined using equation 1. 


$$
C_{i}=\frac{\sum L_{i}}{50}
$$

97 Where i represents the individual species, $\mathrm{L}$ is the intercepting length of the canopy and 50 represents the length of the transect $(50 \mathrm{~m})$.

99

The total canopy cover for each transect was determined by equation 2 .

$$
C_{t}=\sum_{i=1}^{n} C_{i}
$$

100 Where the sum of all individual plant is determined for each transect. Relative canopy cover was 101 determined using equation 3:

$$
R_{i}=\frac{C_{i}}{C_{t}}
$$

103 per individual was calculated using equation 4:

$$
D_{i}=\frac{\sum d_{i} L_{i}}{50}
$$

104 In equation 4, the nomenclature is the same as equation 1 and $d_{i}$ is the proportion of observed

105 canopy dieback per individual. Using the dieback per individual, we were able to calculate total 106 dieback (equation 5) and total living canopy cover (equation 6):

$$
\begin{gathered}
T D=\sum_{i=1}^{n} D_{i} \\
C_{i}-i \sum_{i=1}^{n} D_{i}=C_{t}-T D \\
C_{l}=\sum_{i=1}^{n} i
\end{gathered}
$$




$$
P D_{i}=\frac{D_{i}}{C_{i}}
$$

Proportional dieback for a single growth form was the total dieback distance of species in a particular growth form divided by the total cover of that growth form. Proportional dieback was used in all analyses of dieback.

In 2010 (pre-drought), we collected 3-8 leaves per individual for 2-3 individuals per species at each elevation. We did not collect leaves from succulents (Cactaceae, Nolinaceae and Agavaceae). We used a flatbed scanner and LAMINA software (Bylesjö et al. 2008) to calculate leaf area. After leaf area was recorded, the leaves were dried for 24 hours at $85{ }^{\circ} \mathrm{C}$ and then weighed to determine the dry mass of the leaf. The LMA was calculated as dry mass over area $\left(\mathrm{g} / \mathrm{cm}^{2}\right)$. The weighted LMA on each transect was the average of the species' LMA values on that transect weighted by each species relative cover.

\subsection{Statistical Analysis}

All data were analyzed using R (R Development Core Team 2013). All data were tested using a Shapiro-Wilk test of normality in $\mathrm{R}$ which confirmed that the response variables were normally distributed. Statistical differences across elevations were determined using ANCOVA models. For the analysis of total, living, and relative canopy cover, hierarchical linear models were run with elevation and year of data collection as fixed effects. Transects were nested within elevations: with one site per elevation, we have a sample size of six with which to detect elevational trends. Models were fit with the nlme package in R (Pinheiro et al. 2013). For models predicting relative canopy cover and dieback by elevation and growth form, transect was a random effect (due to multiple dieback estimates per transect) within elevation. The data for total and living cover were untransformed because they met the assumption of normality and were not true proportions. However prior to analysis, proportional dieback and relative cover were 
transformed using an empirical logit transformation $(\ln ((\mathrm{p}+\varepsilon) /(1-(\mathrm{p}+\varepsilon)$, where $\varepsilon=0.0001)$ as those measurements were true proportions (Warton \& Hui 2011). For the analysis of wLMA by proportional dieback across elevations, a nested linear model was used (transects nested within elevation). Post-hoc analyses were done on the wLMA and proportional dieback including and excluding the conifer species. Additional analyses where the sites were grouped by high and low elevation were also performed.

\section{RESULTS}

Total canopy cover (both living and dead canopy combined) for all growth forms increased significantly with elevation $(\mathrm{F}=17.34, \mathrm{p}=0.014)$. In 2010 and 2011, the lowest elevation had $\sim 80 \%$ less cover than the highest (Fig 1). Total canopy cover did not change significantly between years $(\mathrm{F}=1.549, \mathrm{p}=0.217)$, but there was a significant interaction between elevation and year $(\mathrm{F}=6.895, \mathrm{p}=0.010)$ with the highest elevations dropping slightly in total cover by the 2011 measurement (possibly a result of a slight underestimation of total cover for trees with some dieback and with leafless canopy that year). The relative cover of the four perennial woody growth forms (trees, shrub, subshrub, and succulent) differed significantly across elevation (empirical logit transformed, $\mathrm{F}=69.36, \mathrm{p}<0.0001$, Fig 2). There was no significant difference in relative cover between years and no interaction between year and growth form. Succulent and shrub species were present at all elevations. Subshrubs were present at all elevations except the highest elevation, $1920 \mathrm{~m}$. Tree species were present at the two highest elevations, 1920 and 1690 m. Growth forms showed differing elevational patterns in relative cover (significant interaction between growth form and elevation, $\mathrm{F}=36.57, \mathrm{p}<0.0001$, Fig 2). 
154 amount of dieback was consistent across elevations. Because high elevations had much higher

155 initial cover, however, this resulted in much lower proportional dieback at the higher elevations:

156 living canopy cover decreased by $17 \%$ at the highest elevation, $1920 \mathrm{~m}$, and by $83 \%$ at the lowest

157 elevation, $666 \mathrm{~m}$.

158 Proportion dieback decreased significantly with elevation in succulent and shrub species

159 (logit transformed, $\mathrm{F}=8.867, \mathrm{p}=0.04$ ). There was no effect of growth form on proportional

160 dieback $(\mathrm{F}=0.844, \mathrm{p}=0.473)$, but there was an interaction between growth forms and elevation

$161(\mathrm{~F}=7.245, \mathrm{p}=0.0002$, Fig 4). Proportional dieback for each site varied from 0.90 (succulents at

$1621132 \mathrm{~m}$ ) to 0.03 (succulents at $1920 \mathrm{~m}$ ) (Untransformed means, Table 2). The overall elevational

163 trend was driven by succulent and shrub species for which dieback decreased with elevation (Fig

$1644)$.

There was no relationship between wLMA and dieback across transects within elevations

(nested ANCOVA, $\mathrm{F}=2.096, \mathrm{p}=0.152$ ). Because conifer and angiosperm leaves differ in gross

morphology, we also conducted a similar nested ANCOVA which excluded conifers. Those

results were consistent with the analysis including conifers: there was no relationship between

wLMA and dieback $(\mathrm{F}=0.034, \mathrm{p}=0.855)$ nor was there an interaction wLMA and elevation

$(\mathrm{F}=0.550, \mathrm{p}=0.463)$. We also grouped sites into two elevation classes and ran the nested

ANCOVA with elevation class ("high" = 1920, 1690, and $1411 \mathrm{~m}$ and "low" =1132, 841, $666 \mathrm{~m}$ )

172 as a factor. There was no relationship between wLMA and dieback $(\mathrm{F}=0.992, \mathrm{p}=0.326)$ nor was

173 there an interaction between wLMA and elevation class when conifers were included $(\mathrm{F}=0.017$,

$174 \mathrm{p}=0.898)$ or excluded $(\mathrm{F}=0.088, \mathrm{p}=0.768)$.

175 4. DISCUSSION 
As in most arid mountain ranges, total woody plant cover increased with elevation

177 (Whitaker \& Neiring1964 1965, Fig 1). The lack of significant difference in total canopy cover

across years indicates that our sampling methods were consistent across years despite the large amount of dead canopy at some elevations in 2011-with the possible exception that we may have slightly underestimated total cover in 2011 at the highest elevation site (Fig 1). The change in canopy cover from dominantly trees at higher elevations to shrubs at lower elevations was the expected community turnover in Big Bend National Park (Fig 2). Living canopy cover was affected by the drought of 2011 and living cover was significantly reduced in 2011 at all elevations, as would be expected (Fig 3). However, the large degree to which living cover decreased in 2011 (largest decrease at $1411 \mathrm{~m}$ from 0.65 to 0.35 ) was striking. We expected the extreme drought event to overwhelm some of the adaptations that the lower elevation species had for drought. However, as the dieback data indicates, this drought affected all growth forms at all elevations. The impacts of drought across growth forms resulted in the relative abundance of each growth form at a given elevation (measured by living cover) not changing as a result of the drought. Because most of our sites were on a north to northwest facing aspect with less solar radiation than southern aspects, it is likely that the dieback measured in this study is a conservative estimate of the amount of dieback that occurred in Big Bend National Park in 2011. By the end of 2011, the Chisos Basin (1615 m), the Panther Junction (1140 m), and the Rio Grande Village (566 m) meteorological stations had only received about 22\%, 21\%, and 39\% of their normal average precipitation at each location annually (NOAA 2013). This decrease in available water would have increased the likelihood that all woody species experienced stress in xylem transport potentially leading to hydraulic failure. Kukowski, Schwinning, \& Schwartz (2012) reported extensive tree dieback due to hydraulic failure in the Edwards Plateau of Central Texas after the 2011 drought. Our study showed total dieback did decrease significantly with 
elevation and increasing precipitation. Additionally, this drought was coupled with an unusual multi-day freezing event in February 2011 (Poulos 2014, NOAA 2013). The freeze in 2011 affected the various elevations differently (Table 3). The interaction of freezing and drought may have exacerbated hydraulic failure (Langan, Ewers, \& Davis 1997, Cavender-Bares \& Holbrook 2001, Martinez-Vilata \& Pockman 2002). It is likely that the freeze also contributed to the extensive succulent mortality we witnessed, but there is not an obvious difference in the departure from average across the elevations: at all three meteorological stations, there were about 1.5 times as many freezing days as normal in February 2011 (Table 3).

Although the greatest reduction in precipitation and the most prolonged freezing temperatures were at the highest elevations, the effect of the drought (and possibly freezing) were most severe at the lower elevations in terms of proportional canopy dieback (NOAA 2013). Therefore, it seems likely that the more severe effects at low elevation are due to species at those sites being closer to physiological thresholds. This is consistent with our first hypothesis that the lower elevations would experience more dieback due to lower precipitation and/or soil moisture. One site $(871 \mathrm{~m})$ defied the trend: this site had less dieback than the next higher site $(1132 \mathrm{~m}$, Fig 4). This was most likely due to the topography of the site at $871 \mathrm{~m}$. That site was characterized by a gentle slope, but in a drainage that could have led to extra water being funneled to the site through runoff.

elevation (Fig 4). The overall trend was decreasing dieback with elevation, but this was driven by the dominant shrub and succulent growth forms. Trees only occurred at two elevations and we therefore cannot test an elevational effect. Tree dieback levels were intermediate in comparison with the range of values seen for shrubs across elevations (Fig 4). There was no effect of elevation on dieback in subshrub species. For subshrub species, the lack of differences in dieback 
was due to where they were located and their responses to drought. There were very few subshrubs at $1690 \mathrm{~m}$, so their dieback would have little influence on the overall dieback for the subshrubs. Additionally, subshrubs have a woody base and herbaceous annual growth. We hypothesize that there was little canopy dieback in subshrubs because, while the woody stems persisted, the herbaceous growth on the subshrubs never leafed out in 2011 due to the drought. The previous year's growth dried and abscised prior to our measurements, therefore there was less cover to measure in 2011. The drought did not affect subshrubs through canopy dieback, but rather through preventing growth.

The shrubs were greatly affected by the drought at all elevations lower than $1690 \mathrm{~m}$ (Fig 4). Plants exhibit different strategies to deal with drought including variation in rooting depth, variation in ability to prevent water loss, and differences in tissue-specific drought resistance (Schwinning \& Ehleringer 2001, Chesson et al 2004, Ogle \& Reynolds 2004). Despite this, we saw significant mortality across both evergreen and deciduous species. Significant change in total living cover across elevations was driven by the magnitude of dieback in shrub species (Fig 4). The succulent species were expected to be able to tolerate the drought better than the other growth forms as a result of water efficient CAM photosynthesis and large reservoirs of water stored in their stems. However, even for succulents, there was significant dieback at the lower elevations and little dieback at the higher elevations. The severity of the drought (or the combination of drought and freezing) at Big Bend National Park was too stressful for the succulents at the lower elevations.

The relationship between elevation and dieback is not explained by differences in wLMA among species for which leaf traits were collected. Leaf traits were only collected on shrub, subshrub, and tree species. There was no relationship between LMA and dieback on a species or growth form basis. The species at the lower elevations are adapted to drought by 
producing small, easily replaceable leaves, and while investment per leaf area was generally higher at higher elevations, there was no effect of wLMA on dieback within elevations (data not shown). This does not mean that growth form and wLMA were not factors in tolerance to the drought, but with our data, elevation alone is the strongest predictor of the impact of the 2011 drought and freeze event. Despite the desert species in the lower elevations having adaptations for drought tolerance, the historic severity of the 2011 drought overpowered those adaptations which led to higher dieback in drought tolerant species.

\section{CONCLUSION}

The 2011 drought in Big Bend National Park had a large impact on all plant communities, with the relative effects decreasing with elevation. Our data imply that differences in canopy cover and dieback among elevations were probably driven by differences in absolute drought and freezing severity and not by turnover in growth forms and not by turnover in growth forms, or leaf trait differences. Species turnover within growth forms (e.g. variation in drought tolerance within the diverse shrub group) may have played a role in the elevational trend, but we cannot test that with our data. We can say, however, that the decreasing dieback with elevation was not driven by shifts in the relative abundance of shrubs, succulents and trees. Nor was an easily measurable leaf trait, LMA, driving the observed trend.

We cannot distinguish the relative influence of drought and freezing on these communities, but we suspect that freezing may be an important environmental factor in this system. One possibility is that the freezing event most severely impacted low elevation species, and the resultant low elevation mortality masked differences in drought susceptibility (although meteorological data suggest that, historically, winter freezes are just as common at low elevations as they are at the higher). We believe the most likely explanation is that this extreme drought pushed all species to the edge of their tolerances. The widespread dieback of slow-growing shrub 
272 and succulent species in the lower elevations of Big Bend National Park will likely have long273 term effects on the plant community.

274 Acknowledgements

275 276
We thank Joe Sirotnak at Big Bend National Park for his assistance and we thank Brandon Pratt and the students in Ecological Strategies of Plants; Will Brewer, Tony Cullen, Shirali Davé, Thomas Fitzgibbons, Maria Gaetani, Nathan Geiger, Hasitha Guvvala, Audrey Harrell, and Caleb Hill for their contributions to data collection. We thank Michael Huston, Rita QuiñonesMagalhães, Susanne Schwinning and an anonymous reviewer for their comments which improved this manuscript.

\section{References}

Allen, R. B., R.K. Peet, \& W. L. Baker. 1991. Gradient analysis of latitudinal variation in southern Rocky Mountain forests. Journal of Biogeography. 18:123-139.

Bylesjö, M., V. Segura, R.Y. Soolanayakanahally, A.M. Rae, J. Trygg, P. Gustafsson, S. Jansson, \& N.R. Street. 2008. LAMINA: a tool for rapid quantification of leaf size and shape parameters. BMC Plant Biology. 8:82. DOI:10.1186/1471-2229-8-82.

Cavender-Bares J. \& N.M. Holbrook. 2001. Hydraulic properties and freezing-induced cavitation in sympatric evergreen and deciduous oaks with contrasting habitats. Plant, Cell and Environment. 24: 1243-1256. DOI: 10.1046/j.1365-3040.2001.00797.x 
Chesson, P., R.L.E. Gebauer, S. Schwinning, N. Huntly, K. Wiegand, M.S.K. Ernest, A. Sher, A. Novoplansky, \& J.F. Weltzin. 2004. Resource pulses, species interactions, and diversity maintenance in arid and semi-arid environments. Oecologia. 141: 236-253

Combs, S. 2011. The Impact of the 2011 Drought and Beyond. The office of the State Comptroller of Public Accounts, Texas. Publication No. 96-1704.

Du Rietz, G. E. 1931. Life-forms of terrestrial flowering plants. I. Acta Phytogeographica Suecica. 3: 95 pp.

Kukowski, K.R., S. Schwinning, \& B. F. Schwartz. 2012. Hydraulic responses to extreme drought conditions in three co-dominant tree species in shallow soil over bedrock. Acta Oecologica. 171:1-12.

Jacobsen, A. L., R.B. Pratt, S.D. Davis, \& F.W Ewers. 2008. Comparative community physiology: nonconvergence in water relations among three semi-arid shrub communities. New Phytologist. 180: 100-113.

Langan, S.J., F.W. Ewers, \& S.D Davis. 1997. Xylem dysfunction caused by water stress and freezing in two species of co-occurring chaparral shrubs. Plant, Cell \& Environment 20: 425-437.

Lloret, F., D. Siscart, \& C. Dalmases. 2004. Canopy recovery after drought dieback in holm-oak Mediterranean forests of Catalonia (NE Spain). Global Change Biology. 10:2092-2099. DOI: $10.1111 / \mathrm{j} .1365-2486.2004 .00870 . \mathrm{x}$

Martinez-Vilalta J. \& W.T. Pockman. 2002. The vulnerability to freezing-induced xylem cavitation of Larrea tridentata (Zygophyllaceae) in the Chihuahuan desert. American Journal of Botany. 89: 1916-1924. 
312 Merriam, C. H. 1890. Results of a biological survey of the San Francisco Mountain region and desert of the Little Colorado in Arizona. North American Fauna. 3:1-4.

314 Monneveux, P. \& E. Belhassen. 1996. The diversity of drought adaptation in the wide. Plant $315 \quad$ Growth Regulations. 20:85-92.

316

317

Muller, C.H. 1940. Oaks of Trans-Pecos Texas. American Midland Naturalist 24: 703-728. DOI: $10.2307 / 2420868$.

Neilsen-Gammon, J. W. 2011. The 2011 Texas Drought; A Briefing Package for the Texas Legislature. Page 43. Office of the State Climatologist.

NOAA. 2013. National Climatic Data Center. http://www.ncdc.noaa.gov/oa/ncdc.html (Accessed 15 August 2013)

Noy-Meir, I. 1973. Desert ecosystems: environment and producers. Annual review of ecology and systematics. 4:25-51.

Ogle, K. \& J.F. Reynolds. 2004. Plant responses to precipitation in desert ecosystems: integrating functional types, pulses, thresholds, and delays. Oecologia. 141: 282-294.

Pinheiro, J, D. Bates, S. DebRoy, D. Sarkar \& the R Development Core Team. 2013. nlme: Linear and Nonlinear Mixed Effects Models. R package version 3.1-109.

Pockman, W.T. \& J.S. Sperry. 2000. Vulnerability to xylem cavitation and the distribution of Sonoran desert vegetation. American Journal of Botany. 87:1287-1299.

Poulos H.M. 2014. Tree mortality from a global-change type drought coupled with a shortduration freezing event in a Southwestern piñon-juniper woodland, USA. PeerJ PrePrints 2:e237v1 DOI:http://dx.doi.org/10.7287/peerj.preprints.237v1 
Powell, AM 1997. Trees \& Shrubs of the Trans-Pecos and Adjacent Areas. University of Texas Press, $517 \mathrm{pp}$.

R Core Team. 2013. R: A language and environment for statistical computing. R Foundation for Statistical Computing, Vienna, Austria. URL http://www.R-project.org/.

Robertson, T.R., J.C. Zak, \& D. T. Tissue. 2009. Precipitation magnitude and timing differentially affect species richness and plant density in the sotol grassland of the Chihuahuan Desert. Oecologia. 162:185-197.

Schwinning, S. \& J.R. Ehleringer. 2001. Water use trade-offs and optimal adaptations to pulsedriven arid ecosystems. Journal of Ecology, 89:464-480. DOI: 10.1046/j.13652745.2001.00576.x

Schwinning, S. \& O.E. Sala. 2004. Hierarchy of responses to resource pulses in arid and semiarid ecosystems. Oecologia. 141: 211-220. DOI: 10.1007/s00442-004-1520-8

Sperry, J. S. \& T. Ikeda. 1997. Xylem cavitation in roots and stems of Douglas-fir and white fir. Tree Physiology. 17: 275-280.

Warshall, P. 1995. The Madrean Sky Island archipelago: a planetary overview. Biodiversity management of the Madrean Archipelago: the Sky Islands of southwestern United States and northwestern Mexico. USDA Forest Service 5-18.

Warton, D.I. \& F. K.C. Hui. 2011. The arcsine is asinine: the analysis of proportions in ecology. Ecology. 92:3-10.DOI:http://dx.doi.org/10.1890/10-0340.1

Whittaker, R.H. \& W.A. Niering. 1964. Vegetation of the Santa Catalina Mountains, Arizona. I. Ecological Classification and Distribution of Species. Journal of the Arizona Academy of Science. 3: 9-34. 
355 Whittaker, R.H. \& W.A. Niering. 1965. Vegetation of the Santa Catalina Mountains, Arizona: A 356 Gradient Analysis of the South Slope. Ecology. 46:429-452.

357 Whittaker, R. H. \& W.A. Niering. 1968. Vegetation of the Santa Catalina Mountains, Arizona III. 358 Species Distribution and Floristic Relations on the North Slope. Journal of the Arizona $359 \quad$ Academy of Science. 5:3-21.

360 Witkowski, E. T. F. \& B.B. Lamont. 1991. Leaf specific mass confounds leaf density and $361 \quad$ thickness. Oecologia. 88: 486-493.

362 Wright, I.J., P.B. Reich, \& M. Westoby. 2001. Strategy shifts in leaf physiology, structure and 363 T. Chapin, J. H.C. Cornelissen, M. Diemer, J. Flexas, E. Garnier, P. K. Groom, J. Gulias, K. Hikosaka, B. B. Lamont, T. Lee, W. Lee, C. Lusk, J. J. Midgley, M.L. Navas, U. Niinemets, J. Oleksyn, N. Osada, H. Poorter, P. Poot, L. D. Prior, V. I. Pyankov, C. Roumet, S. C. Thomas, M. G. Tjoelker, E. J. Veneklaas, \& R. Villar. 2004. The worldwide 370 leaf economics spectrum. Nature. 428: 821-827. 


\section{Figure 1}

Total canopy cover by elevation in 2010 and 2011 .

Symbols represent the mean \pm 1 standard deviation. Circles and a solid line represent 2010 while triangles and a dashed line represent 2011. There was a significant increase in cover with elevation $(\mathrm{F}=17.34, \mathrm{p}=0.014)$ and interaction in cover between years and elevation $(F=6.895, p=0.010)$.

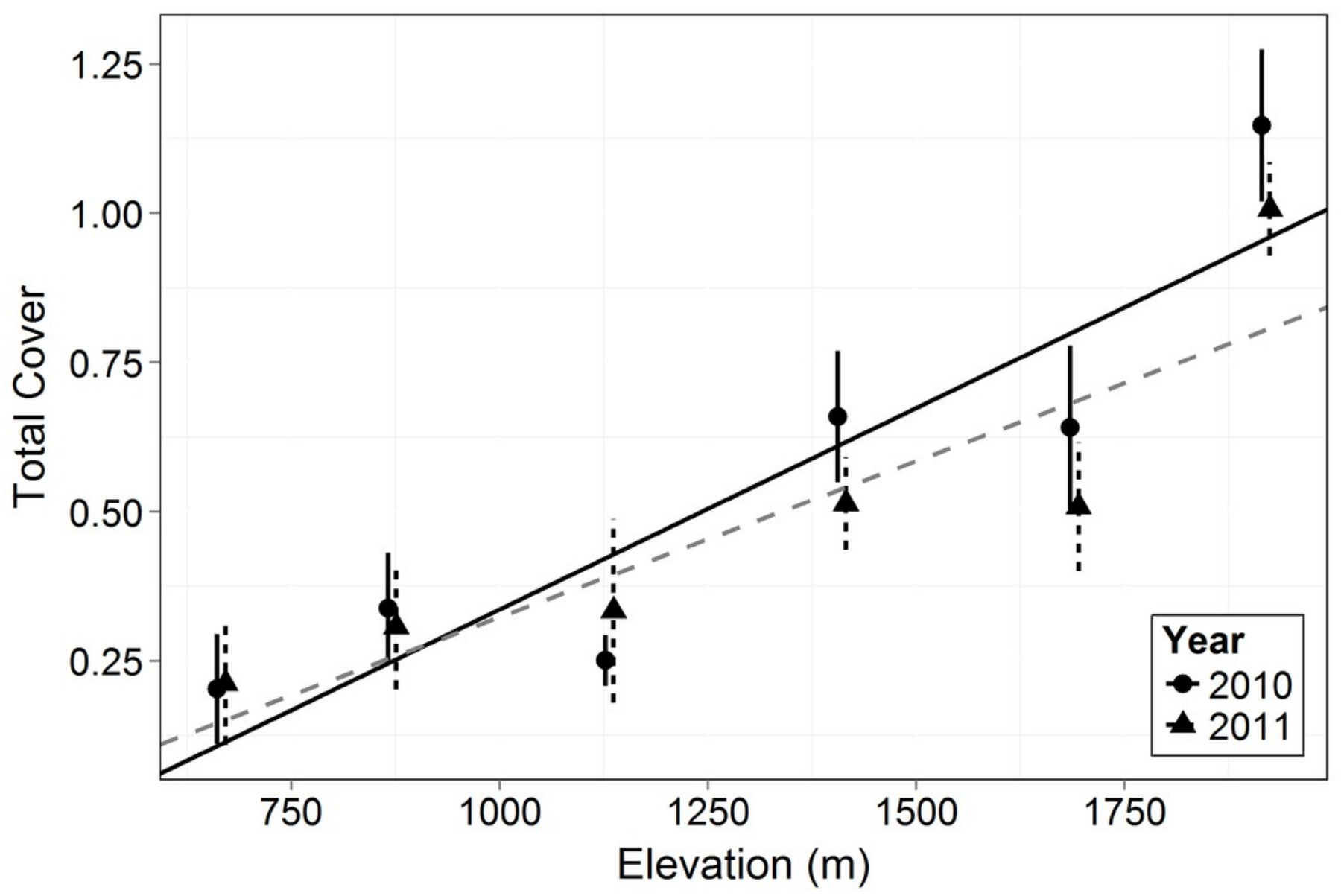




\section{Figure 2}

Relative cover (logit transformed) of different growth forms by elevation in 2010.

Figure shows the cover of each growth form relative to the total canopy cover (see equation 3). This figure shows the changes in growth forms on an elevational gradient. Circles represent the mean \pm 1 standard deviation. Only 2010 is shown in the figure as there was no significant difference between years $(\mathrm{F}=3.473, \mathrm{p}=0.064)$. There was no significant difference among the growth form cover across elevations $(F=0.0466, p=0.840)$. However, there was a significant difference in the relative cover of the growth forms $(F=69.36, p<0.0001)$ and in the interaction of growth form with elevation $(F=36.57, p<0.0001)$.

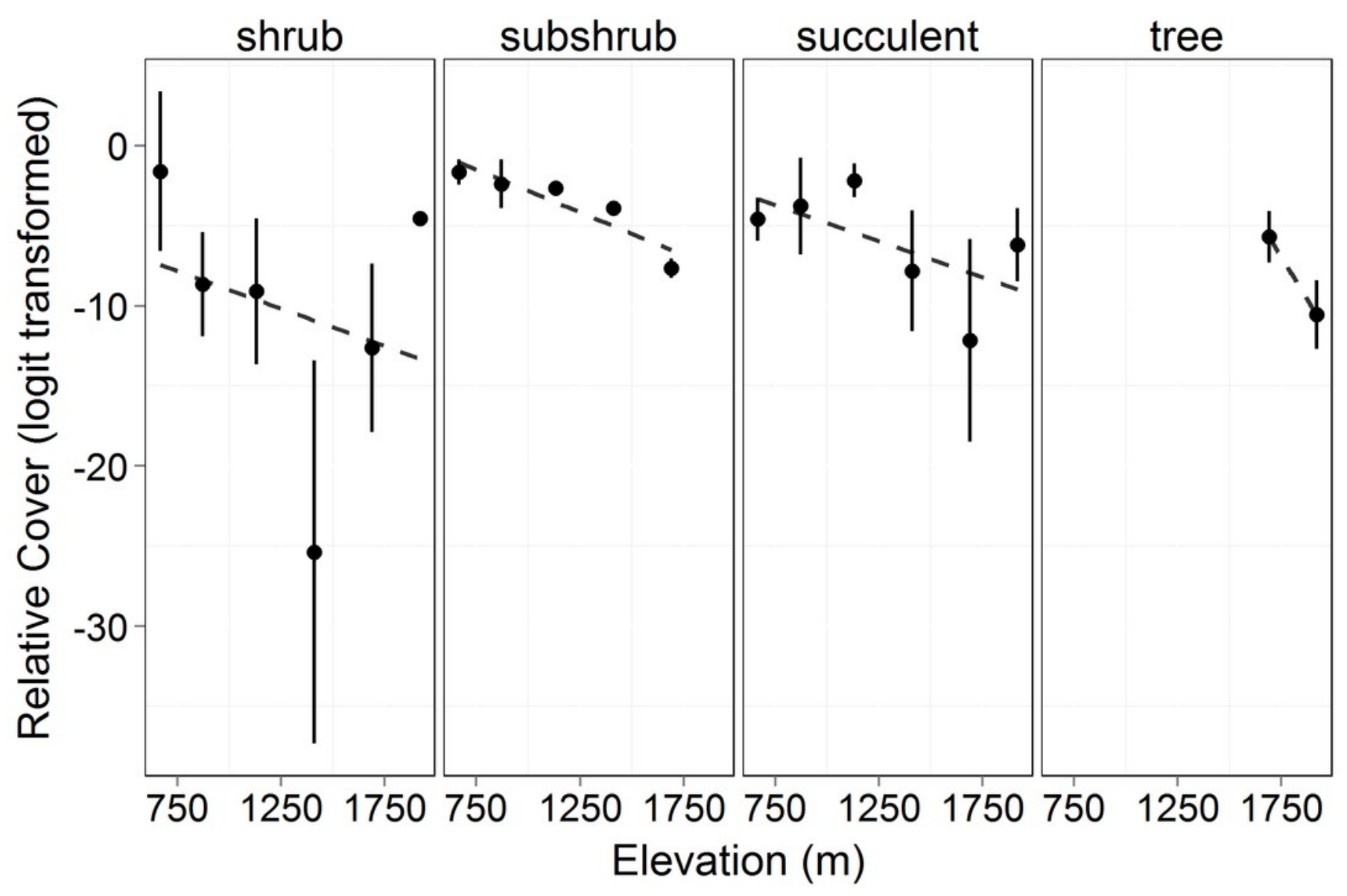




\section{Figure 3}

Total living canopy cover by elevation in 2010 and 2011.

Symbols represent the mean \pm 1 standard deviation. Circles and a solid line represent 2010 while triangles and a dashed line represent 2011. Living cover increased significantly with elevation ( $F=18.33, p=0.013)$ and there was a significant decrease in 2011 compared to 2010 across elevations $(F=103.6, p<0.0001)$.

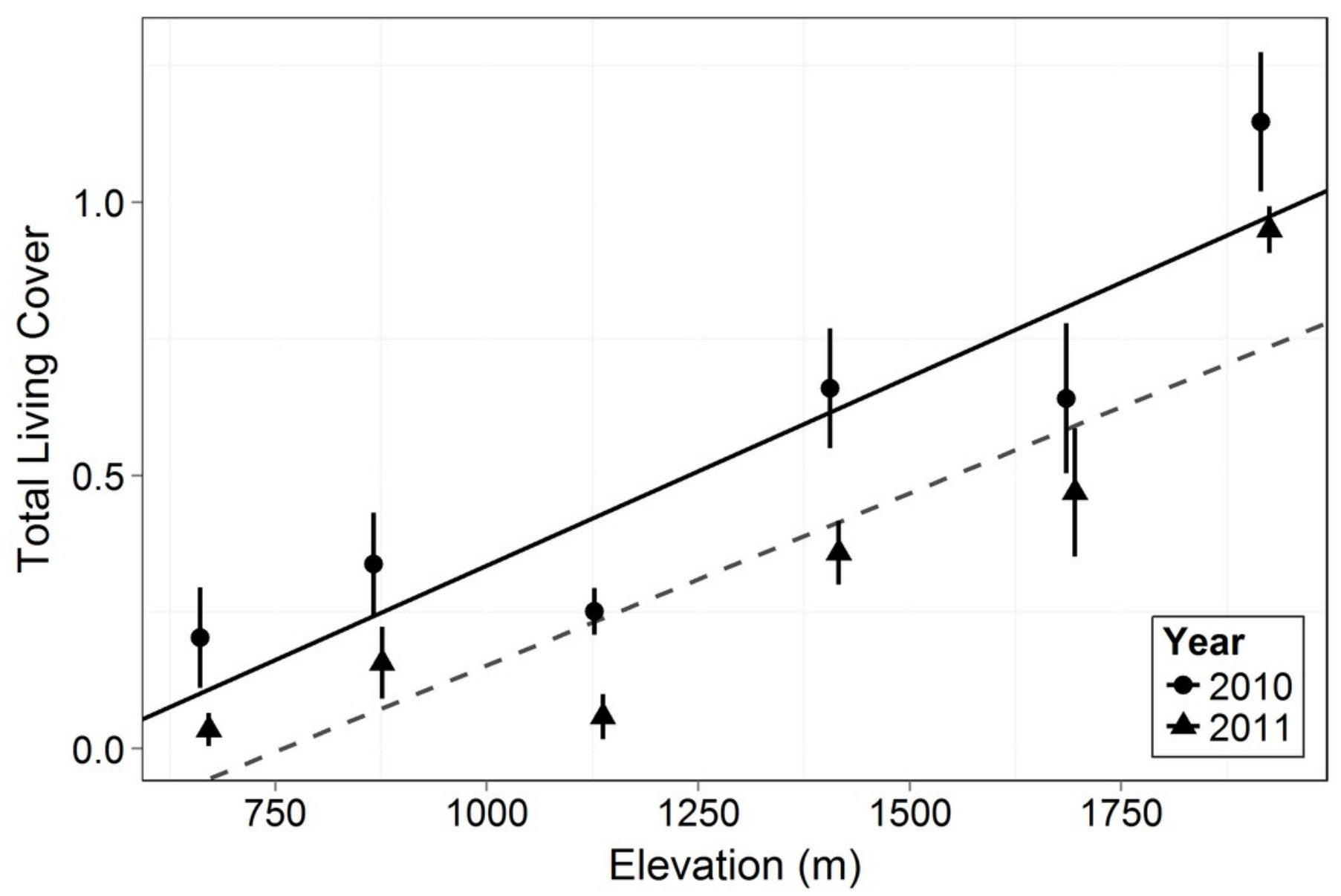




\section{Figure 4}

Proportional canopy dieback (logit transformed) in 2011 by elevation.

Circles represent the mean \pm 1 standard deviation. Figure shows the amount of dieback at each elevation in proportion to the amount of total cover measured (see equation 7).

Transformed proportional dieback decreased with elevation across all growth forms $(\mathrm{F}=8.867, \mathrm{p}=0.04)$. There was no significant difference in proportional dieback among growth forms $(F=0.844, p=0.473)$, but there was an interaction between growth form and elevation $(F=7.245, p=0.0002)$.

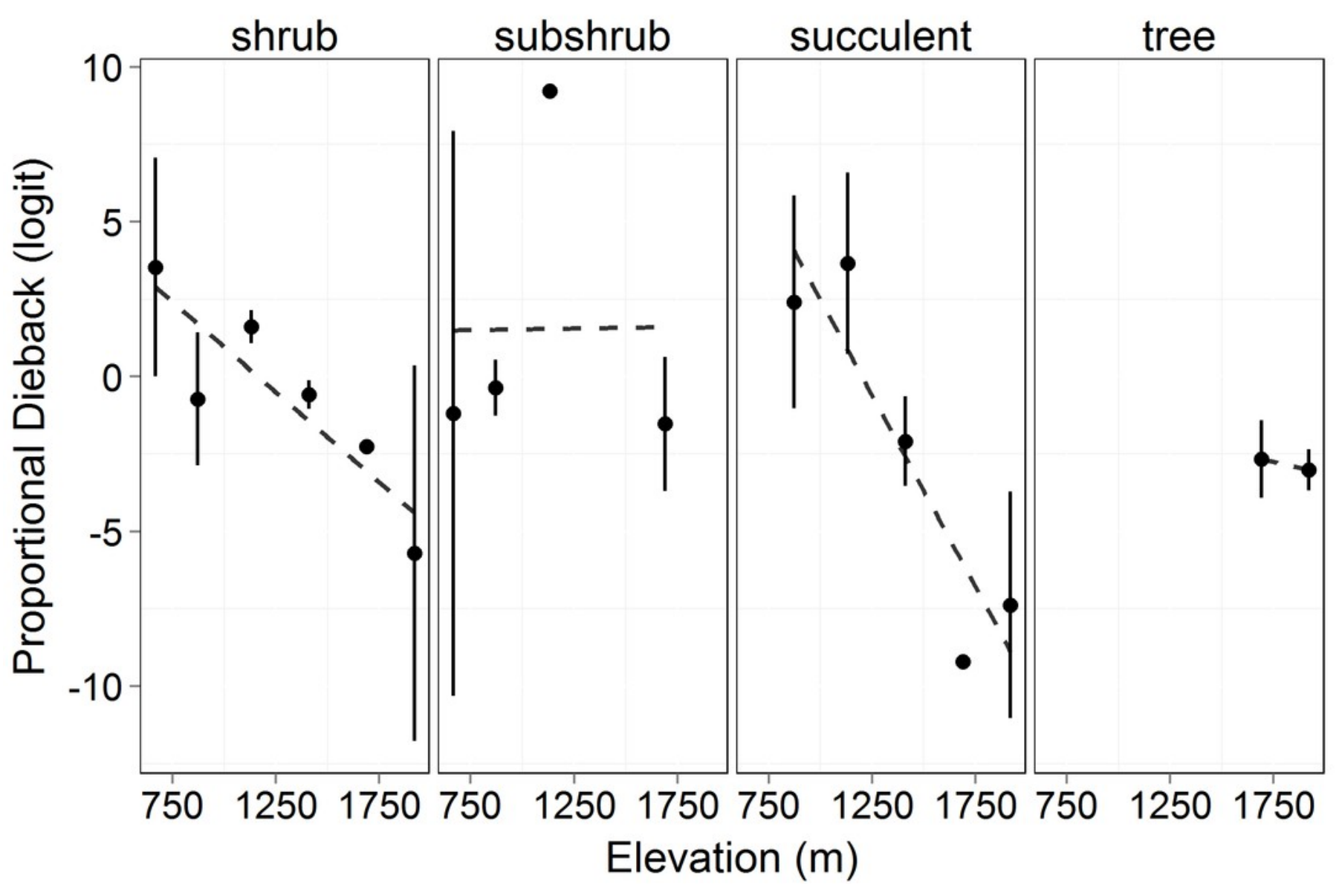




\section{Table 1 (on next page)}

Site descriptions.

A description of the each collection site as well as information of the woody species that were present at each site. 


\begin{tabular}{|c|c|c|c|c|c|}
\hline $\begin{array}{l}\text { Elevation } \\
\qquad(\mathrm{m})\end{array}$ & $\begin{array}{l}\text { Location } \\
\text { (latitude and } \\
\text { longitude) }\end{array}$ & $\begin{array}{l}\text { Number } \\
\text { of } \\
\text { Transects }\end{array}$ & $\begin{array}{l}\text { Dominant Growth } \\
\text { Form }\end{array}$ & $\begin{array}{c}\text { Most Common Species } \\
\text { in Transects }\end{array}$ & Aspect \\
\hline 666 & $\begin{array}{l}29^{\circ} 8.24^{\prime} \mathrm{N} \\
103^{\circ} 30.8^{\prime} \mathrm{W}\end{array}$ & 12 & Deciduous shrub & Larrea tridentata & Flat \\
\hline 871 & $\begin{array}{c}29^{\circ} 10.8^{\prime} \mathrm{N} \\
103^{\circ} 25.8^{\prime} \mathrm{W}\end{array}$ & 10 & Desert shrub & $\begin{array}{l}\text { Agave lechuguilla } \\
\text { Jatropha dioica } \\
\text { Larrea tridentata }\end{array}$ & Flat \\
\hline 1132 & $\begin{array}{l}29^{\circ} 21.2^{\prime} \mathrm{N} \\
103^{\circ} 16.7^{\prime} \mathrm{W}\end{array}$ & 9 & Desert shrub & $\begin{array}{l}\text { Acacia greggii } \\
\text { Agave lechuguilla }\end{array}$ & Flat \\
\hline 1411 & $\begin{array}{c}29^{\circ} 18.2^{\prime} \mathrm{N} \\
103^{\circ} 15.9^{\prime} \mathrm{W}\end{array}$ & $\begin{array}{l}7(2010) \\
5(2011)\end{array}$ & Shrub & $\begin{array}{c}\text { Acacia constricta } \\
\text { Dasylirion leiophyllum } \\
\text { Opuntia chisosensis }\end{array}$ & North \\
\hline 1690 & $\begin{array}{l}29^{\circ} 16.0^{\prime} \mathrm{N} \\
103^{\circ} 18.1 \mathrm{~W}\end{array}$ & $\begin{array}{l}4(2010) \\
5(2011)\end{array}$ & Tree & $\begin{array}{c}\text { Juniperus species (J. } \\
\text { coahuilensis, } \\
\text { deppeana,flaccida, and } \\
\text { pinchotii) } \\
\text { Opuntia chisosensis }\end{array}$ & Northwest \\
\hline 1920 & $\begin{array}{c}29^{\circ} 15.2^{\prime} \mathrm{N} \\
103^{\circ} 18.0^{\prime} \mathrm{W}\end{array}$ & 4 & Tree & $\begin{array}{c}\text { Juniperius deppeana } \\
\text { Quercus species }(Q . \\
\text { emoryii, gravesii, and } \\
\text { grisea) }\end{array}$ & Northwest \\
\hline
\end{tabular}




\section{Table 2 (on next page)}

Proportional dieback of growth forms by elevation.

Each cell shows the untransformed mean proportional dieback of each growth form across elevations \pm 1 standard deviation. The bottom row is the total mean of proportional dieback for all growth forms at each elevation. If a growth form was not measured at an elevation, it is represented with a NA. 


$\begin{array}{ccccccc} & \mathbf{1 9 2 0} \mathbf{~ m} & \mathbf{1 6 9 0} \mathbf{~ m} & \mathbf{1 4 1 1} \mathbf{~ m} & \mathbf{1 1 3 2} \mathbf{~ m} & \mathbf{8 7 1} \mathbf{~ m} & \mathbf{6 6 6} \mathbf{~ m} \\ \text { Shrub } & 0.26 \pm 0.45 & 0.10 \pm 0.02 & 0.36 \pm 0.11 & 0.82 \pm 0.08 & 0.35 \pm 0.28 & 0.85 \pm 0.12 \\ \text { Subshrub } & \text { NA } & 0.29 \pm 0.20 & \text { NA } & 1.00 \pm 0 & 0.42 \pm 0.19 & 0.42 \pm 0.49 \\ \text { Succulent } & 0.03 \pm 0.07 & 0 \pm 0 & 0.17 \pm 0.14 & 0.90 \pm 0.11 & 0.74 \pm 0.32 & \text { NA } \\ \text { Tree } & 0.05 \pm 0.03 & 0.10 \pm 0.07 & \text { NA } & \text { NA } & \text { NA } & \text { NA } \\ \text { Total } & \mathbf{0 . 1 0} \pm \mathbf{0 . 2 3} & \mathbf{0 . 1 1} \pm \mathbf{0 . 1 4} & \mathbf{0 . 2 7} \pm \mathbf{0 . 1 6} & \mathbf{0 . 8 8} \pm \mathbf{0 . 1 1} & \mathbf{0 . 5 0} \pm \mathbf{0 . 3 1} & \mathbf{0 . 6 8} \pm \mathbf{0 . 3 8}\end{array}$




\section{Chisos Basin (1615 m)}

\section{Panther Junction (1140 m)}

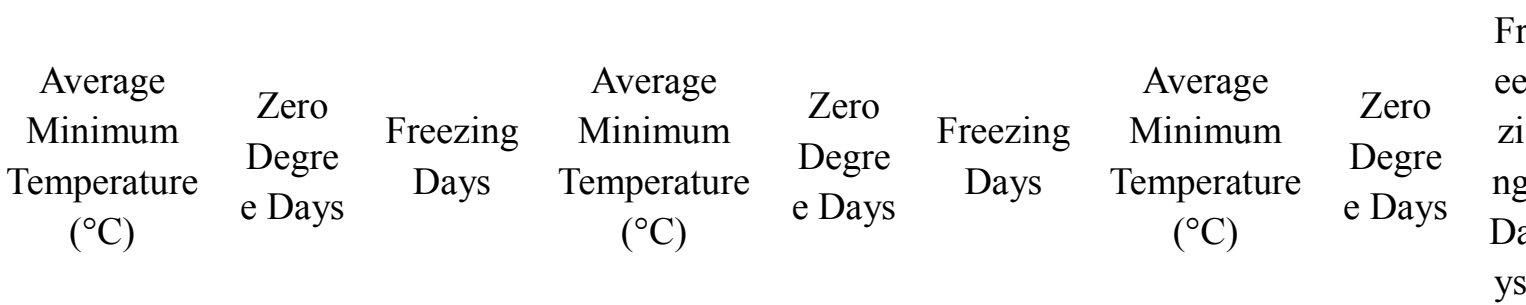

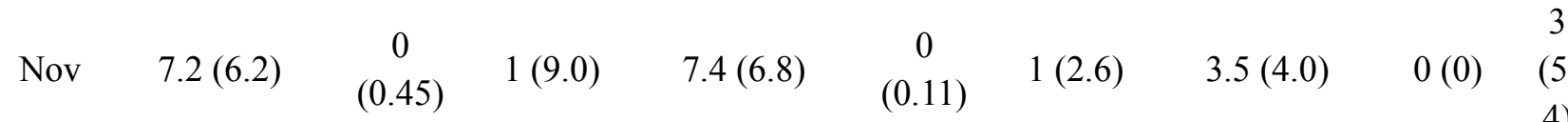

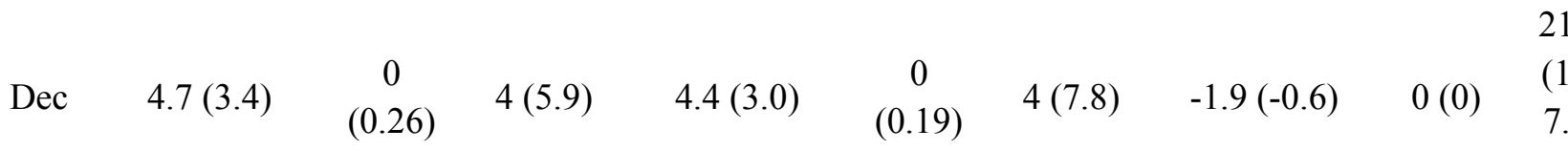

8 8)

$\begin{array}{lcccccccc} & & & & & & \\ & & & & & \\ (2\end{array}$

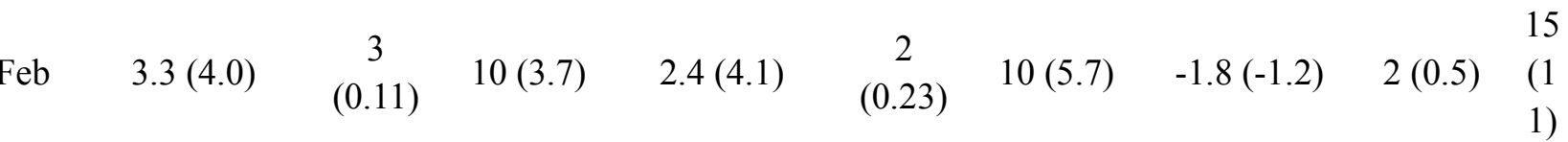

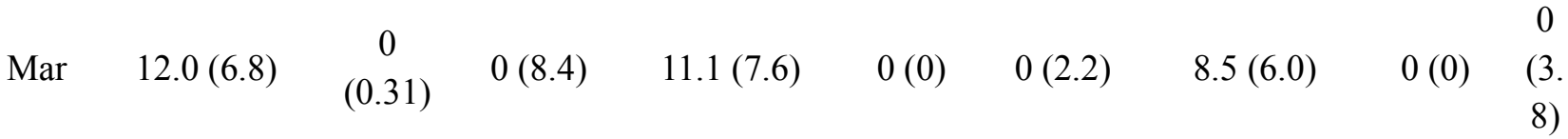

$\begin{array}{lccccccccc} & & & & & 60 \\ & & & & & & & \\ 5\end{array}$
6)

$(5$

8.

6) 